\title{
RESPONS TANAMAN BUNCIS TIPE TEGAK (Phaseolus vulgaris L.) TERHADAP PEMBERIAN PUPUK KOMPOS DAN TSP
}

\author{
Response of Upright Type Beans (Phaseolus vulgaris L.) \\ to Compost and TSP
}

\author{
T. Edy Sabli dan Selvia Sutriana \\ Program studi Agroteknologi Fakultas Pertanian Universitas Islam Riau \\ Jl. Kaharuddin Nasution No. 113 Pekanbaru.28284. Telp: 0761-674681; Fax: 0761-674681 \\ Email: selviasutriana@agr.uir.ac.id \\ [Diterima: Juli 2019; Disetujui: Agustus 2019]
}

\begin{abstract}
ABSTRAK
The research was carried out in the experimental farm of the Faculty of Agriculture, Riau Islamic University, Pekanbaru during 6 months from July to December 2017. The study used Completely Randomized Design (CRD) with 2 factors. First factor was goat manure, consisting of 5 levels: $0,5,10,15,20$ tons/ha and the second factor was TSP fertilizer, consisting of 4 levels: 0,100 , $175,250 \mathrm{~kg} / \mathrm{ha}$. The materials used were bean seeds of the Balitsa-2 variety, goat manure, TSP fertilizer, Urea, KCl, Furadan 3G, Curacon 500 EC, Fungicide (Antracol), and $1 \mathrm{~kg}$ clear plastic. Parameters observed were flowering age, harvest age, number of pods per plant, pod weight per plant, pod length, and number of the remaining fruit. The tools used are a hoe, machete, rake, hand sprayer, analytical scale, meter, stationery, and camera. The results of the observations were analyzed statistically, and the further test was significantly different at a significant level of 5\%. The results showed that the interaction and main effect of goat manure and TSP had a significant effect on all observated parameters. The best treatment was goat manure with a dose of $5-20$ tons/ha and TSP at a dose of $100-250 \mathrm{~kg} / \mathrm{ha}$.
\end{abstract}

Keywords: Uprigh type beans, Compost, TSP, Production

\begin{abstract}
ABSTRAK
Penelitian dilaksanakan di kebun Percobaan Fakultas Pertanian Universitas Islam Riau, Pekanbaru selama 6 bulan terhitung dari Juli sampai Desember 2017. Bahan-bahan yang digunakan adalah benih buncis varietas balitsa-2, pupuk kandang kambing, pupuk TSP, Urea, KCl, Furadan 3G, Curacon 500 EC, dan Fungisida (Antracol), plastik bening ukuran $1 \mathrm{~kg}$. Alat-alat yang digunakan adalah cangkul, parang, garu, handsprayer, timbangan analitik, meteran, alat-alat tulis, kamera. Penelitian menggunakan Rancangan Acak Lengkap (RAL) faktorial dengan 2 faktor, pertama yaitu pupuk kandang kambing terdiri dari 5 taraf: $0,5,10,15,20$ ton/ha dan kedua pupuk TSP terdiri dari 4 taraf: $0,100,175,250 \mathrm{~kg} / \mathrm{ha}$. Hasil pengamatan dianalisis secara statistik dan uji lanjut beda nyata jujur taraf $5 \%$. Parameter pengamatan yaitu umur berbunga, umur panen, jumlah polong per tanaman, berat polong per tanaman, panjang polong, dan jumlah buah sisa. Hasil penelitian menunjukkan bahwa Pengaruh interaksi dan utama pupuk kandang kambing serta TSP memberikan pengaruh nyata terhadap semua parameter pengamatan. Perlakuan terbaik pupuk kandang kambing dosis $5-20$ ton/ha dan TSP dosis $100-250 \mathrm{~kg} / \mathrm{ha}$.
\end{abstract}

Kata kunci: Buncis, Kompos, TSP, Produksi

\section{PENDAHULUAN}

Buncis salah satu jenis sayuran polong yang digemari oleh masyarakat dalam bentuk olahan berbagai jenis masakan dan memiliki manfaat bagi kesehatan. Menurut Cahyono (2007) dalam $100 \mathrm{~g}$ buah buncis segar mengandung: Energi $35 \mathrm{kal}$, Protein 2,4 g, Lemak 0,2 g, Karbohidrat 7,7 g, Kalsium 6,5 g,
Fosfor 4,4 g, Serat 1,2 g, Besi 1,1 g, Vitamin (A 630 SI, B1 0,08 mg, B2 0,1 mg, B3 0,7 mg, C 19,0 mg), dan Air $89 \mathrm{~g}$.

Kebutuhan terhadap buncis cenderung terus meningkat seiring dengan pertambahan jumlah penduduk, dan kesadaran masyarakat tentang pentingnya nilai gizi. Pada Data Badan Pusat Statistik (2016), tercatat bahwa tahun 
2013 produksi buncis 327.378 ton dengan luas areal panen 30.094 ha. Pada tahun 2014 produksi buncis 318.214 ton dengan luas areal panen 28.632. Pada tahun 2015 produksi buncis 291.314 ton dengan luas areal panen mencapai 25.645 ha. Untuk provinsi Riau produksi digolongkan dalam pengelompokkan sayuran dan tergolong rendah, salah satunya dipengaruhi oleh tingkat kesuburan tanah.

Upaya yang dapat dilakukan untuk memperbaiki dan meningkatkan kesuburan tanah adalah dengan pemberian pupuk organik dan anorganik yang berimbang. Penggunaan pupuk yang berimbang mampu mencukupi nutrisi yang dibutuhkan tanaman, serta memperbaiki sifat fisika, kimia, dan biologi tanah.

Musnamar (2004), menyatakan Pupuk kandang kambing merupakan salah satu pupuk organik yang menyediakan unsur hara makro $(\mathrm{N}, \mathrm{P}, \mathrm{K})$ dan mikro $(\mathrm{Ca}, \mathrm{Mg}, \mathrm{S}, \mathrm{Na}, \mathrm{Fe}, \mathrm{Cu}$, Mo). Kadar $\mathrm{N}$ pada pupuk kandang kambing cukup tinggi, dibandingkan dengan pupuk kandang sapi, pupuk kandang kuda dan pupuk kandang babi (Tan KH dalam Yurnalis, 2006). Selain itu, penggunaan pupuk organik memiliki daya ikat ion tinggi sehingga mampu mengefektifkan penggunaan pupuk anorganik yang mudah menguap dan tercuci oleh penyiraman atau air hujan.

Kandungan unsurhara N, K dan $\mathrm{Ca}$ dalam pupuk kandang kambing cukup tinggi, untuk unsur $\mathrm{P}$ masih rendah dan belum dapat untuk memenuhi kebutuhan unsur fosfor untuk tanaman. Tanaman sangat membutuhkan unsur $\mathrm{P}$, karena unsur $\mathrm{P}$ mempunyai manfaat membantu pembentukan protein dan mineral yang sangat penting bagi tanaman, merangsang pertumbuhan dan perkembangan akar, mempercepat pembungaan dan pembuahan pada tanaman buncis.

Pupuk TSP (Triple Super Fosfat) merupakan sumber unsur fosfor yang kadarnya praktis hampir seluruhnya dapat melarut dalam air. Unsur $\mathrm{P}$ sangat penting dalam proses fotosintesis dan fisiologis kimia tanaman. Sumber utama fosfat adalah batu fosfat yang telah melewati proses pengasaman atau pemanasan untuk mendapatkan larutan fosfat (Agromedia, 2007). Pengisian sel-sel daging buah dengan karbohidrat dan perubahannya menjadi gula selama perkembangan buah serta pematangan buah perlu didukung oleh unsurhara yang cukup dan seimbang terutama pupuk $P$ karena manfaatnya yang dapat mendorong pembentukan bunga dan buah pada tanaman.

\section{BAHAN DAN METODA}

Bahan-bahan yang digunakan dalam penelitian: benih buncis varietas balitsa-2, pupuk kandang kambing, pupuk TSP, Urea, $\mathrm{KCl}$, Furadan 3G, Curacon $500 \mathrm{EC}$, dan Fungisida (Antracol), plastik bening ukuran 1 kg. Alat-alat yang digunakan cangkul, parang, garu, handsprayer, timbangan analitik, meteran, gembor, kamera dan alat-alat tulis.

Penelitian menggunakan Rancang Acak Lengkap (RAL) faktorial dengan 2 faktor, pertama pupuk kandang kambing ada 5 taraf: $0,5,10,15,20$ ton/ha dan kedua pupuk TSP 4 taraf: $0,100,175,250 \mathrm{~kg} / \mathrm{ha}$.

Penelitian dimulai dari pengolahan lahan dengan luas $9 \mathrm{~m} \times 12 \mathrm{~m}$, ukuran plot $90 \mathrm{~cm} \times$ $80 \mathrm{~cm}$ sebanyak 60 plot, kemudian label penelitian dipasang untuk memudahkan dalam perlakuan dan pengamatan. Penanaman 1 benih buncis varietas Balitsa-2 pada setiap lubang tanam, dengan jarak tanam $30 \times 40 \mathrm{~cm}$, satu plot terdapat 6 tanaman dan 4 tanaman sebagai sampel. Pemberian perlakuan pupuk kandang kambing seminggu sebelum tanam, dengan cara diaduk rata dengan tanah sesuai dosis perlakuan dan Pupuk TSP diberikan satu kali pada saat tanam, sesuai dosis perlakuan, dengan jarak $7 \mathrm{~cm}$ dari pangkal batang tanaman. Pemeliharaan meliputi penyiraman, penyiangan, pengajiran, pemangkasan dan pengendalian hama serta penyakit tanaman. Pemanenan tanaman buncis di lakukan pada buah yang sudah memenuhi kriterianya yaitu biji dipolong belum menonjol, polongnya belum berserat, permukaan kulit agak kasar, warna dari polong hijau muda, jika polong dipatahkan akan terdengar bunyi letupan. Panen di lakukan 5 kali dengan interval 7 hari sekali.

Parameter yang diamati adalah umur berbunga, umur panen, jumlah polong per tanaman, berat polong per tanaman, panjang polong dan jumlah polong sisa per tanaman.

\section{HASIL DAN PEMBAHASAN}

\section{Umur Berbunga}

Hasil pengamatan setelah dilakukan analisis ragam menunjukkan bahwa secara interaksi dan utama dosis pupuk kandang kambing dan TSP berpengaruh nyata terhadap umur berbunga tanaman buncis. Rerata hasil 
setelah di uji lanjut BNJ taraf 5\% dapat dilihat

pada Tabel 1.

Tabel 1. Rerata Umur Berbunga Tanaman Buncis dengan pemberian Pupuk Kandang Kambing dan TSP (hari).

\begin{tabular}{cccccc}
\hline \multirow{2}{*}{$\begin{array}{c}\text { Pupuk Kandang } \\
\text { Kambing (ton/ha) }\end{array}$} & $0(\mathrm{P} 0)$ & $100(\mathrm{P} 1)$ & $175(\mathrm{P} 2)$ & Rerata \\
\cline { 2 - 5 } (K0) & $35,67 \mathrm{e}$ & $33,33 \mathrm{~d}$ & $32,67 \mathrm{~cd}$ & $32,00 \mathrm{c}$ & $33,42 \mathrm{c}$ \\
$5(\mathrm{~K} 1)$ & $31,00 \mathrm{c}$ & $30,67 \mathrm{ab}$ & $30,67 \mathrm{ab}$ & $30,00 \mathrm{ab}$ & $30,58 \mathrm{~b}$ \\
$10(\mathrm{~K} 2)$ & $30,67 \mathrm{ab}$ & $30,00 \mathrm{ab}$ & $29,67 \mathrm{ab}$ & $29,67 \mathrm{ab}$ & $30.01 \mathrm{ab}$ \\
$15(\mathrm{~K} 3)$ & $30,67 \mathrm{ab}$ & $29,33 \mathrm{ab}$ & $29,33 \mathrm{ab}$ & $29,00 \mathrm{a}$ & $29,58 \mathrm{a}$ \\
$20(\mathrm{~K} 4)$ & $30,00 \mathrm{ab}$ & $29,67 \mathrm{ab}$ & $29,00 \mathrm{a}$ & $29,00 \mathrm{a}$ & $29,42 \mathrm{a}$ \\
\hline Rerata & $31,60 \mathrm{c}$ & $30,60 \mathrm{~b}$ & $30,27 \mathrm{ab}$ & $29,93 \mathrm{a}$ & \\
\hline KK $=1,79 \%$ & BNJ KP $=1,69$ & BNJ K=0,64 & \multicolumn{3}{c}{ BNJ P = 0,54 }
\end{tabular}

Angka pada baris dan kolom yang diikuti huruf kecil yang sama menunjukkan tidak berbeda nyata menurut uji lanjut BNJ pada taraf $5 \%$.

Data pada Tabel 1 menunjukkan bahwa pengaruh interaksi pupuk kandang kambing dan TSP memberikan umur tercepat berbunga pada kombinasi perlakuan pupuk kandang dosis $5-20$ ton/ha dan TSP dosis $0-250$ $\mathrm{kg} / \mathrm{ha}$. Hal ini berarti pada fase pembungaan tanaman buncis membutuhkan pupuk organik, yang mana kandungan hara pada pupuk kandang kambing sudah mampu memenuhi kebutuhan tanaman, sedangkan pupuk TSP tanpa diberikan sudah dapat berbunga dengan baik walaupun belum maksimal. Penting diketahui bahwa genotype dan lingkungan mempengaruhi terhadap pertumbuhan dan produksi tanaman.

Kombinasi antara pupuk kandang kambing dan TSP dapat memberikan umur berbunga yang lebih cepat pada tanaman buncis. Dalam proses pembungaan tanaman buncis sangat memerlukan kebutuhan akan unsur fosfor $(\mathrm{P})$, jika unsur tersebut tidak terpenuhi secara optimal maka tanaman akan menimbulkan gejala yang abnormal. Dengan adanya pemberian TSP pada tanaman buncis makan unsur $P$ untuk tanaman buncis dapat terpenuhi dengan baik, sehingga dapat mempercepat proses pembungaan pada tanaman buncis.

Banyak keuntungan yang diperoleh dalam menggunakan pupuk organik: 1) Mempengaruhi sifat fisik tanah, warna tanah yang semula cerah akan berubah menjadi kelam setelah pemberian bahan organik, tanah menjadi gembur dan lebih mudah melakukan penetrasi, sehingga pertumbuhan akar lebih baik dan akan memberikan dampak positif terhadap hasil tanaman. 2) Mempengaruhi sifat kimia tanah, kapasitas tukar kation (KTK) dan ketersediaan unsur hara meningkat, asam yang dikandung humus membantu meningkakan proses pelapukan. 3) Memperbaiki sifat biologi tanah, bahan organik akan menambah energi yang diperlukan kehidupan mikroorganisme tanah. Tingginya bahan organik yang diberikan ke tanah akan mempercepat perbanyakan fungi, bakteri, mikro flora, dan mikro fauna tanah (Sutanto, 2003).

\section{Umur Panen (Hari)}

Hasil pengamatan setelah dilakukan analisis ragam, menunjukkan bahwa secara interaksi dan utama dosis pupuk kandang kambing dan TSP berpengaruh nyata terhadap umur panen tanaman buncis. Rerata hasil setelah di uji lanjut BNJ dapat dilihat pada Tabel 2.

Data pada Tabel 2 memperlihatkan bahwa secara interaksi pupuk kandang kambing dan TSP memberikan pengaruh nyata terhadap umur panen tanaman buncis, dimana umur panen tercepat pada pemberian pupuk kandang kambing $5-20$ ton/ha dan $0-250$ $\mathrm{kg} / \mathrm{ha}$. Sama dengan umur berbunga, umur panen juga membutuhkan pupuk kandang kambing dan TSP untuk mempercepat pemasakan buah. Jika pemberian dosis pupuk yang tepat maka penyerapan hara yang dilakukan tanaman akan berlangsung dengan baik, sedangkan jika konsentrasi yang diberikan tidak tepat, maka penyerapan hara pada tanaman buncis juga terhambat.

Menurut Sutanto (2003), umur panen pada suatu jenis tumbuhan sangat berkaitan dengan umur berbunga, semakin cepat umur berbunga, maka umur panen juga akan semakin cepat. Hal ini disebabkan karena proses pemasakan buah pada tanaman yang muncul bunga lebih dulu akan lebih efektif dengan rentang waktu yang sama dalam pematangan buah, apabila dibandingkan 
dengan tumbuhan yang menghasilkan bunga

lebih lama.

Tabel 2. Rata-rata Umur Panen dengan Pemberian Pupuk Kandang Kambing dan TSP pada Tanaman Buncis (hari).

\begin{tabular}{cccccc}
\hline \multirow{2}{*}{$\begin{array}{c}\text { Pupuk Kandang } \\
\text { Kambing (ton/ha) }\end{array}$} & $0(\mathrm{P} 0)$ & $100(\mathrm{P} 1)$ & $175(\mathrm{P} 2)$ & Rerata \\
\cline { 2 - 4 } 0 (K0) & $49,33 \mathrm{f}$ & $47,33 \mathrm{e}$ & $46,67 \mathrm{de}$ & $46,00 \mathrm{cde}$ & $47,33 \mathrm{c}$ \\
$5(\mathrm{~K} 1)$ & $45,00 \mathrm{bcd}$ & $45,00 \mathrm{bcd}$ & $44,33 \mathrm{a}-\mathrm{d}$ & $44,00 \mathrm{abc}$ & $44,58 \mathrm{~b}$ \\
$10(\mathrm{~K} 2)$ & $44,67 \mathrm{a}-\mathrm{d}$ & $44,00 \mathrm{abc}$ & $43,67 \mathrm{ab}$ & $43,67 \mathrm{ab}$ & $44,00 \mathrm{ab}$ \\
$15(\mathrm{~K} 3)$ & $44,67 \mathrm{a}-\mathrm{d}$ & $43,33 \mathrm{ab}$ & $43,33 \mathrm{ab}$ & $43,00 \mathrm{a}$ & $43,58 \mathrm{a}$ \\
$20(\mathrm{~K} 4)$ & $44,00 \mathrm{abc}$ & $43,33 \mathrm{ab}$ & $43,33 \mathrm{ab}$ & $43,00 \mathrm{a}$ & $43,41 \mathrm{a}$ \\
\hline Rerata & $45,53 \mathrm{c}$ & $44,60 \mathrm{~b}$ & $44,26 \mathrm{ab}$ & $43,93 \mathrm{a}$ & \\
\hline KK $=1,23 \%$ & BNJ KP $=1,69$ & \multicolumn{3}{c}{ BNJ K $=0,64$} & \multicolumn{3}{c}{ BNJ P $=0,54$} & \\
\hline
\end{tabular}

Angka pada baris dan kolom yang diikuti huruf kecil yang sama menunjukkan tidak berbeda nyata menurut uji lanjut BNJ pada taraf $5 \%$.

Balitkabi (2005), pada tanaman leguminosa, fosfor berfungsi mempercepat fiksasi $\mathrm{N}$ dengan mendorong pembungaan dan pembentukan biji dan buah serta mempercepat masak polong. Fosfor sangat penting sebagai sumber energi dalam berbagai aktifitas metabolisme. Salah satu aktifitas metabolisme tersebut adalah fotosintesis. Fosfor yang cukup, laju fotosintesis menjadi lebih optimal sehingga asimilat yang dihasilkan sebagian dimanfaatkan bagi pembentuk dan penyusun organ tanaman seperti batang, sisanya disimpan dalam bentuk protein dan karbohidrat.

Marsono dan Paulus (2002), mengemukakan gejala kekurangan unsur hara fosfor pada tanaman yaitu daun berubah warna tua atau tampak mengkilap kemerahan, cabang dan batang berubah menjdai kuning dan buah kecil. Unsur fosfat juga sangat berguna untuk mempercepat proses pemasakan buah.

\section{Jumlah Polong Per Tanaman}

Hasil pengamatan setelah dilakukan analisis ragam, menunjukkan bahwa baik secara interaksi maupun pengaruh utama pemberian pupuk kandang kambing dan TSP memberikan berpengaruh nyata. Rerata jumlah polong segar per tanaman setelah uji lanjut (BNJ) pada taraf 5\% dapat dilihat pada Tabel 3.

Tabel 3. Rata-rata Jumlah Polong Per Tanaman dengan Pemberian Pupuk Kandang Kambing dan TSP pada Tanaman Buncis (buah).

\begin{tabular}{clllll}
\hline Pupuk Kandang & \multicolumn{4}{c}{ TSP $(\mathrm{kg} / \mathrm{ha})$} & \multirow{2}{*}{ Rerata } \\
\cline { 2 - 4 } Kambing (ton/ha) & $0(\mathrm{P} 0)$ & $100(\mathrm{P} 1)$ & $175(\mathrm{P} 2)$ & $250(\mathrm{P} 3)$ & \\
\hline $0(\mathrm{~K} 0)$ & $36,67 \mathrm{~m}$ & $40,67 \mathrm{l}$ & 44,00 & $49,67 \mathrm{j}$ & $42,75 \mathrm{e}$ \\
$5(\mathrm{~K} 1)$ & $49,33 \mathrm{k}$ & $57,67 \mathrm{ij}$ & $61,67 \mathrm{~g}$ & $66,67 \mathrm{f}$ & $58,58 \mathrm{~d}$ \\
$10(\mathrm{~K} 2)$ & $55,67 \mathrm{j}$ & $59,67 \mathrm{hi}$ & $72,67 \mathrm{e}$ & $77,67 \mathrm{~cd}$ & $66,25 \mathrm{c}$ \\
$15(\mathrm{~K} 3)$ & $68,00 \mathrm{~g}$ & $68,67 \mathrm{~g}$ & $76,67 \mathrm{de}$ & $90,67 \mathrm{a}$ & $75,92 \mathrm{~b}$ \\
$20(\mathrm{~K} 4)$ & $76,00 \mathrm{def}$ & $81,00 \mathrm{bc}$ & $82,00 \mathrm{~b}$ & $92,00 \mathrm{a}$ & $82,75 \mathrm{a}$ \\
\hline Rerata & $57,06 \mathrm{~d}$ & $61,47 \mathrm{c}$ & $67,26 \mathrm{~b}$ & $75,20 \mathrm{a}$ & \\
\hline
\end{tabular}

$\mathrm{KK}=1,83 \% \quad \mathrm{BNJ} \mathrm{KP}=3,70 \quad$ BNJ K $=1,39 \quad$ BNJ P $=1,17$

Angka pada baris dan kolom yang diikuti huruf kecil yang sama menunjukkan tidak berbeda nyata menurut uji lanjut $\mathrm{BNJ}$ pada taraf $5 \%$.

Data pada Tabel 3 menunjukkan bahwa secara interaksi pemberian pupuk kandang kambing dan TSP berpengaruh terhadap jumlah polong segar per tanaman buncis dimana perlakuan terbaik terdapat pada pemberian pupuk kandang kambing $15-20$ ton/ha dan TSP $250 \mathrm{~kg} / \mathrm{ha}$. Baiknya hasil pada perlakuan ini karena dosis pupuk pupuk kandang kambing dan TSP yang tinggi baru akan dapat mencapai hasil yang maksimal.
Kusmanto (2010), menyatakan bahwa dalam efisiensi pemupukan optimal, pupuk yang harus diberikan harus sesuai dengan kebutuhan tanaman, apakah itu dalam jumlah banyak atau sedikit.

Kotoran kambing mengandung $1.19 \%$ $\mathrm{N}, 0.92 \% \mathrm{P} 2 \mathrm{O} 5$, dan $1.58 \% \mathrm{~K} 2 \mathrm{O}$ sehingga semakin tinggi dosis yang diberikan maka akan semakin meningkatkan kandungan hara tanah. Dari berbagai unsur yang ada, nitrogen merupakan unsur yang sangat penting untuk 
pertumbuhan tanaman, unsur nitrogen bermanfaat untuk pertumbuhan vegetatif tanaman. Penggunaan pupuk kandang kambing secara berkelanjutan memberikan dampak positif terhadap kesuburan tanah. Tanah yang subur akan mempermudah perkembangan akar tanaman. Akar tanaman yang dapat berkembang dengan baik akan lebih mudah menyerap air dan unsur hara yang tersedia di dalam tanah sehingga tanaman dapat tumbuh dan berkembang secara optimal serta menghasilkan hasil yang tinggi.

Nuryani, E dkk (2019), menyatakan bahwa peningkatan jumlah polong hingga titik optimum diduga berkaitan dengan fungsi $\mathrm{P}$ yang berperan mendorong pertumbuhan akar, kemudian mengoptimalkan penyerapan air maupun hara. Cahyono (2003) menyatakan bahwa Unsur fosfor bagi tanaman berguna untuk merangsang pertumbuhan akar, khususnya akar bibit dan tanaman muda. Pembentukan akar ini kemudian akan meningkatkan serapan hara dan air yang akan mendukung jalannya proses fotosintesis

\section{Berat Polong Per Tanaman}

Hasil pengamatan setelah dilakukan analisis ragam, menunjukkan bahwa baik secara interaksi maupun pengaruh utama dosis pupuk kandang kambing dan TSP memberikan berpengaruh nyata terhadap berat polong segar per tanaman. Rerata hasil setelah uji lanjut BNJ taraf 5\% dapat dilihat pada tabel 4 .

Tabel 4. Rata-rata Berat Polong Per Tanaman dengan Pemberian Pupuk Kandang Kambing dan TSP pada Tanaman Buncis (gram).

\begin{tabular}{crrrrl}
\hline Pupuk Kandang & \multicolumn{4}{c}{ TSP $(\mathrm{kg} / \mathrm{ha})$} & Rerata \\
\cline { 2 - 5 } Kambing (ton/ha) & $0(\mathrm{P} 0)$ & $100(\mathrm{P} 1)$ & $175(\mathrm{P} 2)$ & $250(\mathrm{P} 3)$ & \\
\hline $0(\mathrm{~K} 0)$ & $240,33 \mathrm{j}$ & $263,33 \mathrm{ij}$ & $289,27 \mathrm{i}$ & $331,37 \mathrm{~h}$ & $281,07 \mathrm{e}$ \\
$5(\mathrm{~K} 1)$ & $321,33 \mathrm{~h}$ & $281,50 \mathrm{i}$ & $402,87 \mathrm{f}$ & $431,00 \mathrm{e}$ & $359,17 \mathrm{~d}$ \\
$10(\mathrm{~K} 2)$ & $360,50 \mathrm{~g}$ & $390,50 \mathrm{f}$ & $474,77 \mathrm{~cd}$ & $484,67 \mathrm{bc}$ & $427,60 \mathrm{c}$ \\
$15(\mathrm{~K} 3)$ & $452,87 \mathrm{de}$ & $453,33 \mathrm{de}$ & $503,80 \mathrm{ab}$ & $512,00 \mathrm{ab}$ & $480,50 \mathrm{~b}$ \\
$20(\mathrm{~K} 4)$ & $489,33 \mathrm{bc}$ & $526,50 \mathrm{a}$ & $507,57 \mathrm{ab}$ & $508,73 \mathrm{ab}$ & $508,03 \mathrm{a}$ \\
\hline Rerata & $372,87 \mathrm{~d}$ & $383,03 \mathrm{c}$ & $435,65 \mathrm{~b}$ & $453,55 \mathrm{a}$ & \\
\hline KK $=2,16 \%$ & BNJ KP $=27,48$ & BNJ K $=10,36$ & BNJ P $=8,69$ & \\
\hline
\end{tabular}

Angka pada baris dan kolom yang diikuti huruf kecil yang sama menunjukkan tidak berbeda nyata menurut uji lanjut BNJ pada taraf $5 \%$.

Data pada Tabel 4 menunjukkan bahwa secara interaksi pemberian pupuk kandang kambing dan TSP berpengaruh terhadap berat polong segar per tanaman buncis dimana perlakuan terbaik terdapat pada pemberian pupuk kandang kambing 115 - 20 ton/ha dan TSP $100-250 \mathrm{~kg} / \mathrm{ha}$. Kombinasi pupuk kandang kambing dan TSP memberikan pengaruh nyata terhadap berat polong buncis, ini diduga karena pupuk kandang kambing mengandung unsur $\mathrm{N}$ dan $\mathrm{K}$ yang cukup tinggi, dimana unsur $\mathrm{K}$ berperan terhadap kualitas buah yang dihasilkan.

Pemberian pupuk kotoran kambing dapat meningkatkan jumlah unsur hara dalam tanah, sehingga pertumbuhan tanaman akan semakin baik dan mempengaruhi laju fotosintesis, akibatnya berat polong buncis akan bertambah. Untuk meningkatkan produktivitas tanaman sayuran dapat dilakukan dengan beberapa cara, salah satunya adalah jenis, dosis dan teknik aplikasi yang tepat (Purwanti dan Susila, 2009).
Hasil polong buncis per tanaman dapat meningkat karena terjadi penambahan unsur $\mathrm{P}$ dari pupuk kandang kambing dan juga TSP. Menurut Mahdiannoor (2012), pupuk kandang kambing dengan kandungan unsurhara $\mathrm{P}$ yang tinggi serta didukung kondisi tanah dengan kandungan unsur hara $\mathrm{P}$ yang tinggi pula sehingga mampu memacu pembentukan bunga pada tanaman kacang panjang.

Unsur P yang disediakan pada waktu ini akan mendukung perkembangan akar muda yang selanjutnya akan mendukung tanaman dalam menyerap hara. Meningkatnya serapan hara ini akan mengoptimalkan proses fotosintesis pada tanaman, sehingga meningkatkan pembentukan asimilat berupa karbohidrat maupun protein yang kemudian akan ditranslokasikan pada bagian cadangan makanan yaitu polong, hal ini yang selanjutnya mempengaruhi berat segar polong

Pupuk yang mengandung fosfor telah terbukti efektif dalam hal perkembangan akar pada tahap pertama pertumbuhan dan setelah itu mereka memiliki efek positif pada hasil polong dan kualitas kacang buncis. 
Penampakan fisik polong yang besar dan bernas terjadi karena cadangan makanan yang ditimbun di polong semakin banyak. Selanjutnya Syafrina (2014), menyatakan bahwa fungsi fosfor bagi tanaman adalah merangsang pertumbuhan generatif seperti pembentukan bunga, pembentukan buah, dan pengisian biji.

\section{Panjang Polong}

Hasil pengamatan setelah dilakukan analisis ragam, menunjukkan bahwa secara interaksi dan utama dosis pupuk kandang kambing dan TSP berpengaruh nyata terhadap panjang polong per tanaman. Rerata hasil setelah uji lanjut BNJ taraf 5\% dapat dilihat pada tabel 5 .

Tabel 5. Rata-rata Panjang Polong Per Tanaman Dengan Pemberian Pupuk Kandang Kambing dan TSP pada Tanaman Buncis (gram).

\begin{tabular}{clllll}
\hline Pupuk Kandang & \multicolumn{4}{c}{ TSP $(\mathrm{kg} / \mathrm{ha})$} & \multirow{2}{*}{ Rerata } \\
\cline { 2 - 4 } Kambing (ton/ha) & $0(\mathrm{P} 0)$ & $100(\mathrm{P} 1)$ & $175(\mathrm{P} 2)$ & $250(\mathrm{P} 3)$ & \\
\hline $0(\mathrm{~K} 0)$ & $9,30 \mathrm{j}$ & $11,87 \mathrm{fg}$ & $11,97 \mathrm{fg}$ & $12,10 \mathrm{f}$ & $11,31 \mathrm{e}$ \\
$5(\mathrm{~K} 1)$ & $10,20 \mathrm{i}$ & $12,77 \mathrm{e}$ & $13,70 \mathrm{abc}$ & $12,80 \mathrm{e}$ & $12,37 \mathrm{~d}$ \\
$10(\mathrm{~K} 2)$ & $10,87 \mathrm{~h}$ & $12,90 \mathrm{e}$ & $13,87 \mathrm{abc}$ & $13,50 \mathrm{bc}$ & $12,74 \mathrm{c}$ \\
$15(\mathrm{~K} 3)$ & $11,47 \mathrm{~g}$ & $12,93 \mathrm{de}$ & $13,83 \mathrm{abc}$ & $14,10 \mathrm{a}$ & $13,08 \mathrm{~b}$ \\
$20(\mathrm{~K} 4)$ & $11,83 \mathrm{fg}$ & $13,40 \mathrm{~cd}$ & $13,93 \mathrm{ab}$ & $14,07 \mathrm{a}$ & $13,31 \mathrm{a}$ \\
\hline Rerata & $10,73 \mathrm{c}$ & $12,74 \mathrm{~b}$ & $13,46 \mathrm{a}$ & $13,31 \mathrm{a}$ & \\
\hline KK $=1,35 \%$ & BNJ KP $=0,53$ & BNJ K $=0,19 \quad$ BNJ P $=0,17$ &
\end{tabular}

Angka pada baris dan kolom yang diikuti huruf kecil yang sama menunjukkan tidak berbeda nyata menurut uji lanjut BNJ pada taraf $5 \%$.

Berdasarkan pada Tabel 5 menunjukkan bahwa pengaruh interaksi memberikan pengaruh terbaik pada perlakuan pupuk kandang kambing 5 - 20 ton/ha dan TSP 175 $250 \mathrm{~kg} / \mathrm{ha}$. Hal ini di duga karena pemberian pupuk kandang kambing dosis rendah sampai tinggi dan pupuk TSP dosis sedang sampai tinggi mampu menyediakan unsur hara yang cukup dan seimbang untuk kebutuhan tanaman.

Pupuk kandang kambing menyediakan unsur hara yang besar terutama unsur Nitrogen, yang berperan penting dalam panjang buah yang dihasilkan. Hal ini sesuai dengan pendapat Ghani (2002), menyatakan bahwa pemupukan $\mathrm{N}$ dapat meningkatnya panjang polong. Unsurhara $\mathrm{N}$ yang diberikan dalam bentuk pupuk berpengaruh terhadap proses fotosintesis dan dapat merubah karbohidrat menjadi protein, sehingga pertumbuhan akan lebih efektif termasuk dalam penambahan panjang buah dan diameter buah.

Unsur hara $\mathrm{P}$ diberikan kedalam tanah maka akan terjadi proses keseimbangan antara larutan dan kompleks padatan, bentuk keseimbangan itu bisa berupa fiksasi ataupun pelarutan unsur lainnya (Ige, 2005). Sutriadi (2010) menyatakan fungsi utama fosfor dalam pertumbuhan tanaman yaitu: Resfirasi dan fotosintesis, penyusun asam nukleat, pembentukan bibit tanaman dan hasil buah, perangsang perkembangan akar, mempercepat masa panen, memacu pembentukan bunga.

\section{Jumlah Polong Sisa Per Tanaman}

Hasil pengamatan setelah dilakukan analisis ragam, menunjukkan bahwa secara interaksi dan utama dosis pupuk kandang kambing dan TSP berpengaruh nyata terhadap jumlah polong sisa per tanaman. Rerata hasil setelah uji lanjut BNJ taraf 5\% dapat dilihat pada Tabel 6.

Data pada Tabel 6 menunjukkan bahwa pengaruh interaksi memberikan pemgaruh nyata dengan perlakuan terbaik pupuk kandang kambing 10 - 20 ton/ha dan TSP 175 - 250 $\mathrm{kg} / \mathrm{ha}$. Hal ini diduga karena dipengaruhi oleh tingkat kemampuan akar tanaman dalam mempertahankan asupan unsur hara secara berkelanjutan untuk mempertahankan hasil produksi agar tetap optimal secara terus menerus.

Suatu tanaman akan menghasilkan produksi yang tinggi secara terus menerus apabila memperoleh asupan unsur hara yang lebih baik dan sesuai dengan yang dibutuhkan tanaman. Sebaliknya tanaman yang hanya memperoleh asupan hara dalam keadaan cukup dan seimbang hanya mampu meningkatkan produksi dalam periode panen tertentu saja tanpa dapat mempertahankan hasil produksi pada periode-periode setelahnya (Sufianto, 2011). 
Tabel 6. Rata-rata Jumlah Polong Sisa Per Tanaman dengan pemberian Pupuk Kandang Kambing dan TSP pada Tanaman Buncis (buah).

\begin{tabular}{|c|c|c|c|c|c|}
\hline \multirow{2}{*}{$\begin{array}{l}\text { Pupuk Kandang } \\
\text { Kambing (ton/ha) }\end{array}$} & \multicolumn{4}{|c|}{$\mathrm{TSP}(\mathrm{kg} / \mathrm{ha})$} & \multirow[t]{2}{*}{ Rerata } \\
\hline & $0(\mathrm{P} 0)$ & $100(\mathrm{P} 1)$ & $175(\mathrm{P} 2)$ & $250(\mathrm{P} 3)$ & \\
\hline $0(\mathrm{~K} 0)$ & $3,67 \mathrm{~h}$ & 6,33 fgh & $8,33 \mathrm{e}-\mathrm{h}$ & $7,00 f g h$ & $6,33 \mathrm{a}$ \\
\hline $5(\mathrm{~K} 1)$ & $5,00 \mathrm{gh}$ & $7,00 \mathrm{fgh}$ & $8,33 e-h$ & $9,67 d-g$ & $7,50 \mathrm{~d}$ \\
\hline $10(\mathrm{~K} 2)$ & $6,67 \mathrm{fgh}$ & $8,33 \mathrm{e}-\mathrm{h}$ & $11,33 \mathrm{c}-\mathrm{f}$ & $16,67 \mathrm{ab}$ & $10,75 \mathrm{c}$ \\
\hline $15(\mathrm{~K} 3)$ & $8,67 \mathrm{e}-\mathrm{h}$ & $8,00 f g h$ & $16,33 \mathrm{abc}$ & $20,67 \mathrm{a}$ & $13,33 \mathrm{~b}$ \\
\hline $20(\mathrm{~K} 4)$ & $13,67 \mathrm{bcd}$ & $13,33 \mathrm{~b}-\mathrm{e}$ & $18,00 \mathrm{ab}$ & $20,33 \mathrm{a}$ & $16,33 \mathrm{a}$ \\
\hline Rerata & $7,46 \mathrm{c}$ & $8,60 \mathrm{c}$ & $12,46 \mathrm{~b}$ & $14,86 \mathrm{a}$ & \\
\hline $\mathrm{KK}=15,14 \%$ & $\mathrm{BNJ} \mathrm{KP}=5,08$ & \multicolumn{3}{|c|}{ BNJ $\mathrm{K}=1,91 \quad$ BNJ P $=1,61$} & \\
\hline
\end{tabular}

Angka pada baris dan kolom yang diikuti huruf kecil yang sama menunjukkan tidak berbeda nyata menurut uji lanjut BNJ pada taraf $5 \%$.

Fosfor yang diberikan pada tanaman juga dapat mempengaruhi berat polong dan kualitas hasil tanaman dan pengisian biji atau polong. Pada saat fase generatif fosfat dibutuhkan tanaman untuk sintesis protein dan proses enzimatik. Dengan demikian, bila pengisian polong berjalan dengan optimal maka polong yang dihasilkan akan lebih bernas.

\section{KESIMPULAN}

Dari hasil penelitian yang telah dilakukan dapat diambil kesimpulan sebagai berikut:

1. Pengaruh interaksi pupuk kandang kambing dan TSP nyata terhadap semua parameter pengamatan. Perlakuan terbaik pupuk kandang kambing dosis 5-20 ton/ha dan TSP dosis 100 - $250 \mathrm{~kg} / \mathrm{ha}$;

2. Pengaruh utama pupuk kandang kambing nyata terhadap semua parameter, perlakuan terbaik dosis 10 ton/ha

3. Pengaruh utama TSP nyata terhadap semua parameter pengamatan, perlakuan terbaik dosis $175 \mathrm{~kg} / \mathrm{ha}$

\section{DAFTAR PUSTAKA}

Agromedia. 2007. Petunjuk Pemupukan. PT.Agromedia Pustaka, Jakarta.

Badan Pusat Statistik. 2016. Produksi dan Luas Lahan Tanaman Sayuran dan BuahBuahan. Badan Pusat Statistik Provinsi Riau, Pekanbaru.

Balitkabi. 2005. Teknologi Produksi KacangKacangan dan Umbi-Umbian. Balai Penelitian Tanaman Kacang-Kacangan dan Umbi-Umbian, Malang.

Cahyono. 2007.Kacang Buncis, Teknik Budidaya dan Analisis Usaha Tani.Kanisius, Yogyakarta
Ghani, M. A. 2002. Buku Pintar Mandor: Dasar-Dasar Budidaya Mentimun. PT. Penebar Swadaya, Jakarta. 134 hal.

Ige DV, OO Akinremi and DN Flaten. 2005. Direct and Indirect Effects of Soil Properties on Phosfhorus Retentionn Capacity. Soil Society of America Journal, 71: 95-100.

Marsono dan Paulus, S. 2002. Pupuk Akar Jenis dan Aplikasinya. Penebar Swadaya. Jakarta.

Mahdiannoor. 2012. Efektivitas Pemberian Trichoderma spp. dan Dosis Pupuk Kandang Kotoran Ayam pada Lahan Rawa Lebak terhadap Pertumbuhan dan Hasil Tanaman Kacang Panjang (Vigna sinensis L.). Jurnal Ziraa'ah, 33(1): 9198.

Musnamar, E. I. 2004. Pupuk Organik Cair dan Padat, Pembuatan, Aplikasi. Penebar Swadaya, Jakarta.

Nuryani, E., Gembong, H., Historiawati. 2019. Pengaruh Dosis dan saat pemberian Pupuk P terhadap Hasil Tanaman Buncis (Phaseolus vulgaris L) Tipe Tegak. Jurnal Ilmu Pertanian Tropika dan Subtropika, 4 (1): 14 - 17.

Purwanti, A dan Susila. 2009. Pengaruh Jenis Pupuk Organik terhadap Pertumbuhan dan Produksi Tanaman Sayuran dalam Nethouse. Makalah Seminar Departermen Agronomi dan Hortikultura Fakultas Pertanian Institut Pertanian Bogor, Bogor

Sutanto, R. 2003. Penerapan Pertanian Organik. Penerbit Kanisius. Jogjakarta

Sufianto.2011. Kriteria Bunga Menjadi Polong Bernas Pada Beberapa Varietas Kacang Tanah (Arachys hipogea L.). Jurnal Gamma 6 (2) : 137-142. 
Sutriadi M.T., S. Rochayati, dan A. Rachman. 2010. Pemanfaatan Fosfat Alam Ditinjau Dari Aspek Lingkungan. Diakses 28 April 2017.

Syafrina. S, 2014. Respon Pertumbuhan dan Produksi Kacang Hijau (Phaseolus radiatus L.) pada Media Subsoil terhadap Pemberian Beberapa Jenis Bahan Organik dan Pupuk Organik Cair. Online pada http:www.google.com: repository.usu.ac.id. Diakses 11 Januari 2018.

Yurnalis. 2006. Pengaruh Aplikasi Pupuk Organik dan Pupuk Anorganik Terhadap Pertumbuhan Produksi Serta Mutu Benih Kacang Tanah (Arachis hypogoea. L). Skripsi Pascasarjana Institut Pertanian Bogor, Bogor. 